\title{
Taxonomic redescription and biological notes on Diaugia angusta (Diptera, Tachinidae): parasitoid of the palm boring weevils Metamasius ensirostris and M. hemipterus (Coleoptera, Dryophthoridae)
}

\author{
Silvio Shigueo Nihei', Ronaldo Pavarini ${ }^{2}$ \\ I Departamento de Zoologia, Instituto de Biociências, Universidade de Säo Paulo, Rua do Matão, Travessa \\ 14, n. 101, 05508-900, Cidade Universitária, São Paulo, SP, Brazil 2 Departamento de Agronomia, Campus \\ Experimental de Registro, Universidade Estadual Paulista, Rua Nelson Bribi Badur, n. 430, 11900-000, \\ Registro, SP, Brazil \\ Corresponding author: Silvio Shigueo Nihei (silvionihei@gmail.com)
}

Academic editor:Martin Hauser| Received 20 November 2010 | Accepted 13 February 2011 | Published 1 March 2011

Citation: Nihei SS, Pavarini P (2011) Taxonomic redescription and biological notes on Diaugia angusta (Diptera, Tachinidae): parasitoid of the palm boring weevils Metamasius ensirostris and M. hemipterus (Coleoptera, Dryophthoridae). ZooKeys 84: 23-38. doi: 10.3897/zookeys.84.756

\begin{abstract}
Diangia angusta Perty, 1833 is a Neotropical species of Tachinidae (Diptera) reported here as a parasitoid of Metamasius ensirostris (Germar, 1824) and M. hemipterus (Linnaeus, 1758) (Coleoptera: Dryophthoridae) in Brazil. Several species of Dryophthoridae and Curculionidae cause damage to bromeliad and palm species, and most are regarded as pests. In the present study, the male and female of D. angusta are morphologically characterized and illustrated to provide a means for the identification of this parasitoid. Data obtained from preliminary field research show that natural parasitism of Metamasius pupae by $D$. angusta varies by year but can reach nearly $30 \%$. A network of parasitoid-host interactions among tachinid parasitoids and coleopteran hosts reported as bromeliad and palm pests (Dryophthoridae and Curculionidae) in the Americas indicates that the species of the tribe Dexiini sensu lato (including D. angusta) might be promising as biological control agents of these pests.
\end{abstract}

\section{Keywords}

Dexiinae, taxonomy, host record, biological control, palm, bromeliad, Brazil, Neotropical Region

Copyright S.S. Nihei, R. Pavarini. This is an open access article distributed under the terms of the Creative Commons Attribution License, which permits unrestricted use, distribution, and reproduction in any medium, provided the original author and source are credited. 


\section{Introduction}

The Neotropical genus Diangia (Tachinidae: Dexiinae: Dexiini) was described by Perty (1833) to include a single new species, $D$. angusta. This species was described based on material collected from state of Minas Gerais in the southeastern Brazil. Since the description, the genus and the species appeared in the literature only through brief citations and catalogues, without any detailed study (Townsend 1939, Guimarães 1971, Tschorsnig 1985). The most relevant studies were made by Charles $\mathrm{H}$. Townsend, including Diaugia in a key to Zeliini genera (Townsend 1936) and providing a morphological diagnosis of the genus (Townsend 1939). In the end of his diagnosis, Townsend (1939: 78) wrote: "Ranges in two species from Minas Geraes [sic] to Rio de Janeiro". Apart from the type-species (D. angusta), from Minas Gerais, Townsend (1939) had therefore regarded the existence of a second undescribed species, from Rio de Janeiro. The material examined by Townsend was found deposited at the Museu Nacional (Rio de Janeiro) and a detailed examination confirmed it to be conspecific with $D$. angusta.

Metamasius Horn (Coleoptera: Dryophthoridae) is a Neotropical weevil genus comprising about 110 species, mostly associated damaging bromeliads, sugarcane, bananas and palms (Vaurie 1966, Frank 1999). Several species are considered important crop pests. Metamasius ensirostris (Germar) is known to cause damages to bananas, sugarcane and palms (Vaurie 1966, Silva 1968). Furthermore, within the attacked palms, there are reports to several species explored for "palmito" (heart-of-palm) extraction in Brazil, as Euterpe edulis Mart. ("juçara"), Euterpe oleracea Mart. ("açaî") and Bactris gasipaes Kunth ("pupunha", peach-palm) (Zorzenon et al. 2000). Metamasius hemipterus (Linnaeus) is an important stem-borer of sugarcane, banana, bromeliads and palms in Central and South Americas, but also introduced to other regions of the world (Vaurie 1966). Metamasius callizona (Chevrolat) is associated with bromeliads and bananas in Central America but, after introduction, it has damaged severely the native bromeliad species in tropical areas of North America (Frank and Cave 2005).

Recently, great efforts have been applied in order to find ways to control the bromeliad and palm weevils, such as the field exploration for parasitoids (Cave et al. 2003), experiments evaluating efficiency of parasitoids (Moura et al. 2006), use of pheromone-based traps (Oehlschlager et al. 1993), among others.

In the present study, comprehensive material of Diaugia from several museums was studied in detail. Within the material, there was one specimen reared on Metamasius ensirostris from the state of Santa Catarina (southern Brazil), and several specimens reared on M. hemipterus from the state of São Paulo (southeastern Brazil). Additionally, there were some specimens from São Paulo reared from an undetermined Metamasius.

This paper aims to provide taxonomic support for the identification of this parasitoid and for its potential use as a biological control agent of Metamasius species. We provide a detailed morphological characterization of Diangia angusta Perty. Both male and female specimens are characterized, the male terminalia are described and illustrated for the first time, and photographs and distribution map are presented. In addition, based on preliminary field research performed in the state of São Paulo (Brazil), 
some biological data on the interaction between Diaugia and Metamasius is presented. Finally, a parasitoid-host network is elaborated showing the interactions between these parasitoid flies (Tachinidae) and coleopteran hosts reported as bromeliad and palm pests (Dryophthoridae and Curculionidae) in the Americas.

\section{Material and methods}

The examined material is deposited at the following institutions: Museu Nacional, Universidade Federal do Rio de Janeiro, Rio de Janeiro, Brazil (MNRJ); and Museu de Zoologia, Universidade de São Paulo, São Paulo, Brazil (MZSP). The morphological terminology follows mainly McAlpine (1981), Wood (1987) and Stuckenberg (1999).

The subfamily and tribal classification of Tachinidae followed here is that used in the latest Nearctic Catalogue by O'Hara and Wood (2004), which basically followed the classification scheme of Herting (1984) and Tschorsnig (1985). One example is Dexiini, into which some tribes were included under its name (e.g., Zeliini, Prosenini, Theresiini as junior synonyms). Even though, the earlier classification of Neotropical Tachinidae (sensu Guimarães 1971) was eventually mentioned during the discussion. In this case, the old names were cited in the following way: "Zeliini", "Theresiini".

To elaborate the network of parasitoid-host interactions, we included all the species of Tachinidae recorded as parasitoids of species of Dryophthoridae and Curculionidae which are reported in the literature as pests of bromeliads and palms in the Americas. However, the network is complete only in that all the hosts of "Zeliini" and all the parasitoids of Dryophthoridae and Curculionidae are presented. For the other taxa in the network, neither all parasitoids nor all hosts are presented. For complementary information about them, please refer to Guimarães (1977, South America) and Arnaud (1978, North and Central Americas). Although out-of-date, these host-parasitoid catalogues still remain as comprehensive and reliable references for the Tachinidae of the Americas for the time coverage.

\section{Systematics}

\section{Diangia Perty, 1833}

Diaugia Perty 1833: 187, type species: Diaugia angusta Perty, 1833 (by monotypy). Diaugia; Townsend 1936: 30 (key to genera of Zeliini), Townsend 1939: 77 (diagnosis), Guimarães 1971: 101 (as 'Diaughia', catalogue, in Zeliini), Tschorsnig 1985: 100 (as 'Diaughia', citation, male terminalia characterization, in Dexiini). Diaughia, error.

Diagnosis. Diaugia differs from other South American Dexiini by the following combination of characters: eye bare; arista densely long plumose; no facial carina; parafacial bare; proepisternum bare; intrapostalar seta absent; 2 katepisternal setae; katepimeron 
(barette) setulose anteriorly; costal spine undeveloped; $\mathrm{R}_{1}$ without setulae; base of $\mathrm{R}_{4+5}$ setulose dorsally and ventrally; abdominal syntergite $1+2$ and tergite 3 without median marginal setae (but females have a pair of median marginal setae on tergite 3 ) and all tergites without discal setae (but some ground setulae rather developed middorsally); male abdomen conspicuously elongate (although not caudate as in Uramya RobineauDesvoidy and Trichodura Macquart).

Among Dexiini, Diaugia undoubtedly resembles the other genera formerly included in the extinct tribe Zeliini (sensu Guimarães 1971, 1975). If valid today, this tribe would include 11 genera, all them monotypic except for Zelia Robineau-Desvoidy with nine species. Although Diaugia may be distinguished from other "Zeliini" and Dexiini (former paragraph), as well as each of the former "Zeliini" genera may bear a set of diagnostic characters, a discussion about the validity of each of these 10 monotypic genera is extremely necessary. On the other hand, to achieve a reliable treatment of these generic names (if valid or not), a detailed and comprehensive revision including types and non-types of all the 11 genera is much required.

\section{Diaugia angusta Perty, 1833}

Figures 1-11

Diangia angusta Perty 1833: 187, plate 37, fig. 9, type locality: Brazil, Minas Gerais, syntype male (lost sec Reiss and Schacht 1983: 308, formerly at the Zoologischen Staatssammlung München), syntype male (USNM, \#A16608, also from Minas Gerais, not examined)

Redescription. Male: Body length: $13.5 \mathrm{~mm}$ (11.5-15.0), wing length: $11.0 \mathrm{~mm}$ $(10.0-12.0)(\mathrm{n}=20)$.

Colouration (Figures 1-7): Frontal vitta dark-brown to black (Figure 3); head silver or light-golden pruinose but gena with reddish dark brown area from the eye lower margin to vibrissal angle (Figures 1). Antenna dark-brown. Palpus yellowish brown; proboscis dark-brown. Thorax dark-brown to black with silver or light-golden pruinosity (Figure 6); the scutum with 4 dark stripes not reaching the scutellum, and the remaining scutum silver pruinose. Wing hyaline, the membrane tinged with light-brown or at least along the veins (Figure 5); calypteres and halter brown. Legs dark brown with silver pruinosity on coxae and femora. Abdomen (Figures 5 and 7) dark brown to black with silver pruinosity on anterior margin of tergites 3 to 5 , and with extensive yellow areas on sides of syntergite $1+2$ and tergites 3 and 4 , both dorsally and ventrally.

Head (Figures 1, 3): Eye apparently bare, with very short and sparse setulae. About 14 pairs of frontal setae. Two minute proclinate fronto-orbital setulae; fronto-orbital plate bare and narrower than frontal vitta and parafacial. Parafacial bare. Facial ridge with few weak setulae near vibrissa. Postpedicel slender, $4 \mathrm{x}$ the length of pedicel; arista long plumose, with 2-3 dorsal and 2 ventral rows (but one single ventral row on basal half), with about same length of postpedicel, and the length of longest cilia about $5 \mathrm{x}$ 



Figures I-4. Diaugia angusta: I male head, lateral view $\mathbf{2}$ female head, lateral view (head partially collapsed) $\mathbf{3}$ male head, frontal view $\mathbf{4}$ female head, frontal view. (Scale bar: $1 \mathrm{~mm}$ )

the basal width of arista. Vibrissa fine and long, inserted at level of lower facial margin. Genal dilation covered by fine pale setulae. Palpus filiform; labella developed, slightly shorter than prementum, which is as long as palpus.

Thorax (Figure 6): Acrostichals 3+1, but a weak pair before the postsutural pair. Dorsocentrals $3+4$, but seems $3+3$ as the second postsutural is weakly developed or indistinct from ground setulae in some specimens. Posthumerals 2 , aligned with the intralar row, the posterior seta stronger and the anterior located lateral to the postpronotum. Presuturals 2, the posterior stronger. Postpronotals 3. Notopleurals 2. Postutural intra-alars 2, the anterior weak; intra-postalar absent. Postsutural supraalars 3, the anteriormost (prealar) weakly developed, about $1 / 3$ the length of the strongest supra-alar and shorter than the first postsutural intra-alar and dorsocentral. Prosternum and proepisternum bare. Six strong anepisternal setae. Katepisternals 2, 

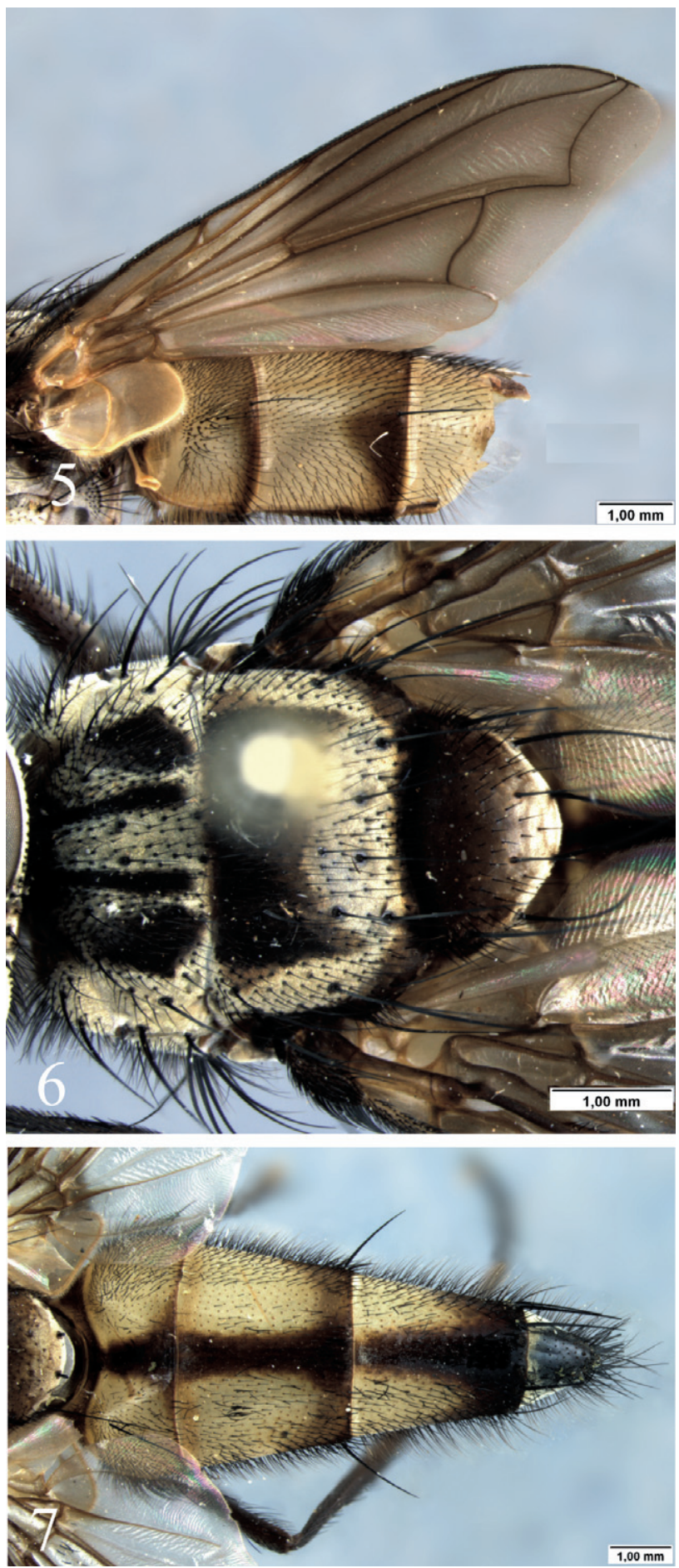

Figures 5-7. Diaugia angusta: 5 male wing, lateral view $\mathbf{6}$ male thorax, dorsal view 7 male abdomen, dorsal view. (Scale bar: $1 \mathrm{~mm}$ ) 
but some specimens with a reduced lower anterior seta is present. Katepimeron (barette) setulose anteriorly. Scutellum with one basal, one lateral, one apical and one discal pairs of setae.

Wing (Figure 5): costal spine undeveloped; base of $\mathrm{R}_{4+5}$ setulose dorsally and ventrally; $\mathrm{M}$ vein bent forward to $\mathrm{R}_{4+5}$, and convex after bend.

Legs: Fore tibia with 2 posterior setae. Mid femur with 2 anterior setae on median third, 2 dorsal preapical setae, and one posterodorsal preapical setae. Mid tibia with 1 submedian anterodorsal seta, 2 posterior setae on apical and basal third (the basal seta weak), and one ventral seta on apical third. Hind tibia with an anterodorsal row of irregularly sized and spaced setae but one strong submedian seta; with one submedian anteroventral and two posterodorsal seta (the submedian stronger).

Abdomen (Figure 7): Abdomen elongate and tapering to apex in dorsal view. Syntergite $1+2$ and tergite 3 each with one lateral marginal seta. Tergite 4 with a marginal row of setae, the ventral setae reduced. Tergite 5 with marginal row of setae, with the ventral setae reduced; no discal setae but the ground setulae rather developed dorsally.

Terminalia (Figures 8-10): Cercal plate enlarged at base and tapering to the apex in posterior view (Figure 9), with long setulae mostly on base, the tip long and narrow and slightly curved inwards, ending before apex of surstylus (Figure 8). Surstylus broad and
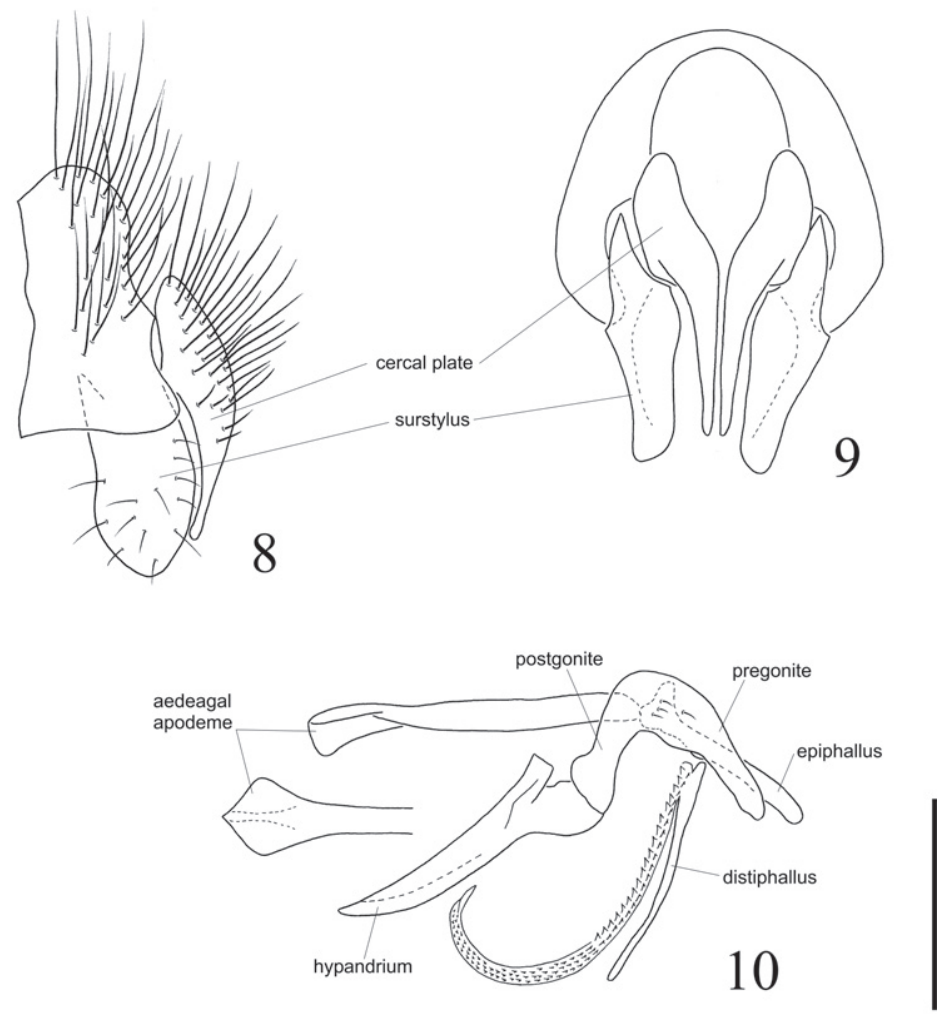

Figures 8-10. Diangia angusta: 8 male terminalia, lateral view 9 male terminalia, posterior view $\mathbf{1 0}$ aedeagus in lateral view and the detail showing the tip of aedeagal apodeme in dorsal view. (Scale bar: $0.5 \mathrm{~mm}$ ) 
the apex rounded, with subparallel margins in lateral view (Figure 9), while in posterior view tapering slightly to the subtruncate apex, the inner surface of surstylus concave. Pregonite and postgonite widely fused as a single piece on each side and firmly connected to the hypandrium (Figure 10); pregonite+postgonite somewhat stout at basal 2/3, strongly curved downwards at middle and tapering to the apex. Aedeagal apodeme straight, with subparallel margins, and elongate, longer than hypandrium (Figure 10). Epiphallus enlarged at base but uniformly narrow until a subtruncate apex, a little longer than half length of aedeagal apodeme. Distiphallus composed of a dorsal sclerite, long, straight and quite narrow, and anteriorly to it, a ventral membrane narrow and extremely elongate. The latter curved at apical half and bearing spinulae all along, these spinulae with their points upwardly oriented and becoming tinier towards the apex (Figure 10).

Female: Body length: $11.0 \mathrm{~mm}(11.5-15.0)$, wing length: $9.0 \mathrm{~mm}(7.5-10.5)(\mathrm{n}=12)$. Differs from male in the following: two strong proclinate fronto-orbital setae (Figures 2, 4); fronto-orbital plate as wide as both frontal vitta and parafacial; fore tibia with 1 posterior seta; abdomen oblong in dorsal view, not elongate as in males, with the yellow areas on sides of syntergite $1+2$ and tergites 3 and 4 less extensive than in male; tergite 3 with a median marginal pair; and tergite 5 with the ground setulae weakly developed.

Intraspecific variation. Within the examined material, the specimens showed some significant intraspecific variation in colouration: body colouration varied from dark brown to black (compare Figures 3 and 4); head and thorax with silver to lightgolden pruinosity (compare Figures 1 and 2, and 3 and 4); wing always hyaline but the membrane tinged throughout with light-brown (Figure 5) or infuscated at least along the veins, and in some specimens with no noticeable infuscation.

Examined material. BRAZIL: Goiás, Anápolis, 1 male, 3.iii.1937, 1 male, vii.1934, Serviço Febre Amarela M.E.S. leg. (MZSP); Rio de Janeiro: Itatiaia, 700m, 1 male, 28.iv.1941, J. F. Zikán leg. (MZSP); Rio de Janeiro, Corcovado (Paineiras), 2 males (MZSP), 1 male (MNRJ), iii.1934, L.T. [Travassos] leg. (MZSP); idem, 1 male, xi.1935, L. Travassos leg. (MNRJ); idem, 1 male, 19.i.1938, Oiticica leg. (MZSP); Rio de Janeiro, Jardim Botânico, 1 male, vi.1935[? year hardly readable], H. S. Lopes leg. (MZSP); São Paulo: Barueri, 1 male, 3.iv.1957, 1 male, 20.iv.1957, 1 male, 20.vi.1957, 1male, 28.xii.1965, 2 males, 15.i.1966, 1 male, vii.1966, K. Lenko leg. (MZSP); Juquiá, 3 males and 3 females, i.2006, R. Pavarini leg. (ex. Metamasius sp. in "pupunha" crop [Bactris gasipaes Kunth]) (MZSP); Pariquera-Açu, 8 males and 11 females, iv-xii.2007, P.H. Silva \& R. Pavarini leg. (ex. Metamasius hemipterus in "pupunha" crop - Bactris gasipaes) (MZSP); Araçatuba, Sítio Santo Amaro, 1 male, 6.i.1963, Rabello leg. (MZSP); Salesópolis, Boracéia, 1 male, 10-14.xi.1947, L. Trav. F., G. Ramalho \& E. Rabello leg. (MZSP); idem, 2 males, 14.viii.1947, E. Rabello, Trav. F. \& J. Lane leg. (MZSP); São Paulo, Ipiranga, 1 male, i.1932, R. Spitz leg. (MZSP); Paraná, Rio Negro, 1 male, 7.i.1929, no collector (MZSP); Santa Catarina: Blumenau, 1 male, xii.1924, Luederwaldt leg. (ex. Metamasius ensirostris) (MZSP); Nova Teutônia, 1 male, iv.1964, 1 male, viii.1967, F. Plaumann leg. (MZSP).

On the type material. Perty (1833:187) described D. angusta without mentioning the composition of the type-series and with no reference to a holotype. Townsend 
(1939: 77) provided a diagnosis of Diaugia in his "Manual of Myiology" and deliberately referred to a 'holotype' and a 'paratype' (deposited at "Munich" and "Washington" respectively). Quite possibly he had not examined the supposed 'holotype' (perhaps only the 'paratype' at the USNM), as there is no clear statement in the brief pages about Diaugia. The male syntype deposited at the Zoologischen Staatssammlung München is lost (Reiss and Schacht 1983: 308), and the only type-material remaining is the male syntype at USNM.

Distribution. BRAZIL (states of Goiás, Minas Gerais, Rio de Janeiro, São Paulo, Paraná, Santa Catarina) (Figure 11).

Habitat characterization. Based on geographical data of the examined material, D. angusta has been recorded in areas covered by Atlantic Forest (Figure 11). Most areas are characterized by dense evergreen ombrophilous tropical forests, whereas there is a single record in semi-deciduous forest (Brazil: São Paulo: Araçatuba). Outside the Atlantic Forest, this species also occurs in drier biomes such as Cerrado (Brazil: Goiás: Anápólis), however, it is very likely that it actually inhabits the gallery forests (humid forests accompanying riverine systems). Additionally, based on the known records, the altitude ranges from sea-level to 900 meters.

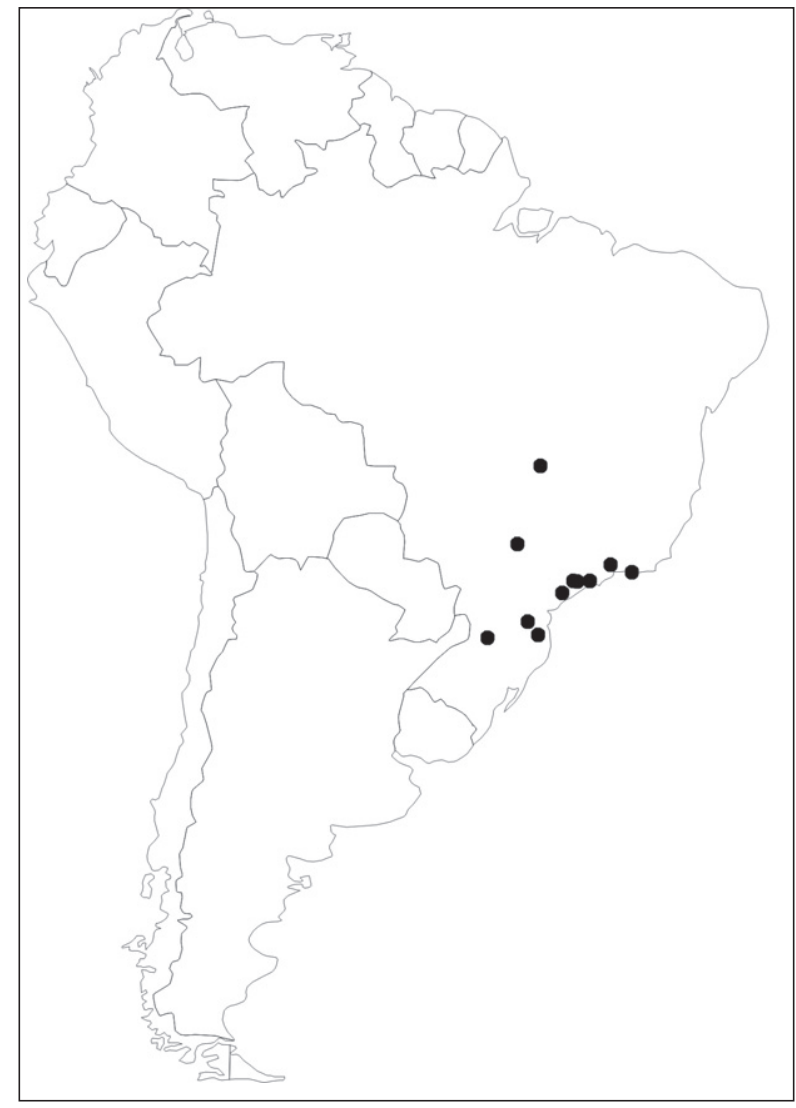

Figure I I. Distribution map of Diangia angusta (black dots). 


\section{Hosts:}

i) Metamasius ensirostris (Germar, 1824) (Coleoptera: Dryophthoridae) (new record) from Blumenau, state of Santa Catarina;

ii) Metamasius hemipterus (Linnaeus, 1758) (new record) from Pariquera-Açu, state of São Paulo;

iii) Metamasius sp. (new record) from Juquiá, state of São Paulo.

\section{Preliminary field research}

The junior author is developing a long-term research project searching for natural enemies of boring weevils attacking peach-palm crops ("pupunha", B. gasipaes). In a noncommercial crop of peach-palms in the municipality of Pariquera-Açu (southernmost of state of São Paulo), larvae of Metamasius sp. (undetermined species) were observed attacking the stems. Population peaks of the weevil were recorded during the months with higher temperatures and higher levels of precipitation.

Between April and December 2007, a survey was conducted to identify parasitoids of Metamasius sp. in that area. A total of 235 pupae were collected in the field and taken to the laboratory (UNESP, Registro-SP), where they were stored individually in small glass vials covered with a polyester-netting cloth. They were maintained under ambient-temperature until the emergence of the host or parasitoid.

Within the 235 field-collected pupae, 23 were parasitized by the tachinid $D$. angusta. This parasitism varied along the time (Figure 12), ranging from $28.57 \%$ in September to $0.00 \%$ in May and December (Figure 13). Although the samples were higher in May (20 pupae) and December (14 pupae) than in September ( 9 pupae), there was no tachinid emergence in May and December. The largest sample was obtained in November with 68 pupae, but only 7 parasitized pupae (10.28\%).

We do not have data available for January, February and March, which are usually the months with the highest levels of precipitation and temperature in the study area. Furthermore, additional field studies are required to obtain reliable and statistically significant data on this interaction. Nevertheless, this preliminary field research indicates that $D$. angusta has a great potential for use in the biological control of Metamasius species in peach-palm crops and, perhaps, in other crops.

\section{Discussion}

\section{Parasitoidism of tachinid flies on Dryophthoridae and Curculionidae bromeliad and palm pests}

The present study reveals important reports of $D$. angusta parasitizing $M$. ensirostris and $M$. hemipterus. These are the first host records for this tachinid species, and absolutely nothing is known about a potential host specialization over M. ensirostris and/or $M$. 




Figure 12. Monthly parasitism of Metamasius sp. by Diaugia angusta (total number of collected pupae and total number of parasitized pupae) from April to December 2007 in Pariquera-Açú (Brazil).

hemipterus. The geographical distribution known for D. angusta ranges from central to southeastern and southern Brazil (Figure 11), while the host M. ensirostris occurs from northern South America (Colombia, Venezuela) southwards to Paraguay, southern Brazil and northern Argentina (Vaurie 1966). And the host M. hemipterus is the most widespread among all the species of Metamasius (Vaurie 1966), occurring in Central and South America (from Mexico to Argentina), with recent introductions reported to other regions (e.g., western Africa, UK, USA, Australia, Philippines) (Vaurie 1966, CABI 2007).

The host-parasitoid network presented in Figure 14 is focused on the interaction between Tachinidae parasitoids and Dryophthoridae and Curculionidae species reported as pest of bromeliads and palms in the Americas. The network is not complete for every species included, as only "Zeliini" has all its hosts and only Dryophthoridae and Curculionidae have all their parasitoids depicted (see Material and Methods for details).

The network (Figure 14) shows that the parasitoid-host relationship is not very well established in terms of species-specific associations. Dryophthoridae species are parasitized by a great variety of tachinids, and these tachinid species develop on several hosts, not only Dryophthoridae. There are only 10 tachinid species connected to 11 dryophthorid species, on the other hand, these 10 tachinids have several other connections (most not shown) to species of Coleoptera and Lepidoptera (Guimarães 1977, Arnaud 1978). The species of "Zeliini" in the network connect to Cerambycidae, Passalidae, Scarabaeidae and Tenebrionidae (Coleoptera); "Theresiini" connects 


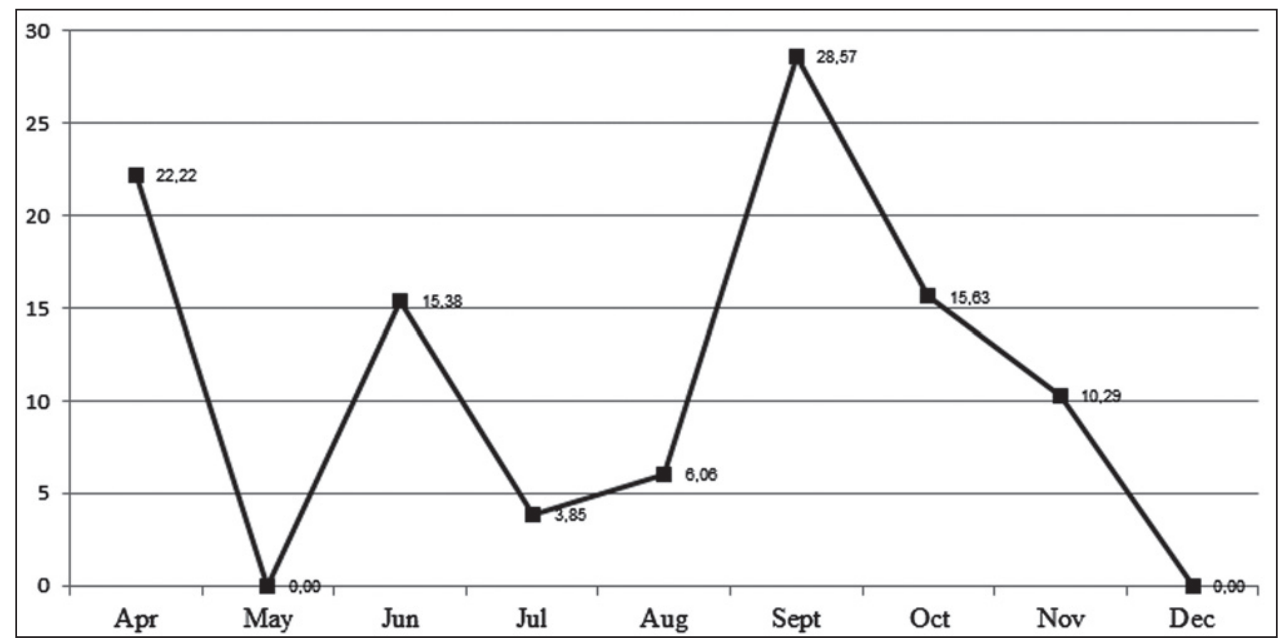

Figure 13. Monthly percentages of parasitism of Diangia angusta on pupae of Metamasius sp. from April to December 2007 in Pariquera-Açú (Brazil).

to Curculionidae (Coleoptera) and Pyralidae (Lepidoptera); Blondeliini connects to Dryophthoridae, Curculionidae, Cerambycidae, Bostrichidae (Coleoptera), Pyralidae, Arctiidae, Hesperiidae, Noctuidae, Olethreutidae, Gelechiidae, Limacodidae, Tortricidae and Noctuidae (Lepidoptera); while Myiophasiini connects to Scarabaeidae and Curculionidae (Coleoptera).

The present study records $D$. angusta to $M$. ensirostris and $M$. hemipterus in southeastern and southern Brazil. Before that, the only host record for a South American "Zeliini" was the one reporting Neozelia alini Guimarães, 1975 on a cerambycid species in southeastern Brazil (Guimarães 1975). Additionally, in North America, Zelia tricolor (Coquillett) parasitizes Rhabdoscelus obscurus (Boisduval) (Dryophthoridae). And, contrary to the apparent specificity observed in "Zeliini", Z. vertebrata (Say) has host species within Passalidae, Scarabaeidae, Tenebrionidae and Cerambycidae (Arnaud 1978) (Figure 14).

Members of "Zeliini" has been recorded on several different and not closely related branches of Coleoptera. On this sense, the Dryophthoridae species are also parasitized by a disparity of tachinid species, belonging to three different subfamilies: Exoristinae (Blondeliini), Tachininae (Myiophasiini) and Dexiinae (Dexiini, "Zeliini”, "Theresiini”) (Guimarães 1977, Moura et al. 2006) (Figure 14).

Although the interactions between Dryophthoridae species and the tachinids Lixophaga Townsend, Ceromasia Rondani and Gnadochaeta Macquart seem to be specific, this is an artefact as the network does not show all the host associations recorded to these tachinid genera. North American species of Gnadochaeta parasitize Sphenophorus spp. (Dryophthoridae), but there are also records to several other host species among Curculionidae (Coleoptera), and among lepidopterans Arctiidae, Pyralidae and Noctuidae (Arnaud 1978). Moreover, other Myiophasiini parasitize members of Scarabaei- 


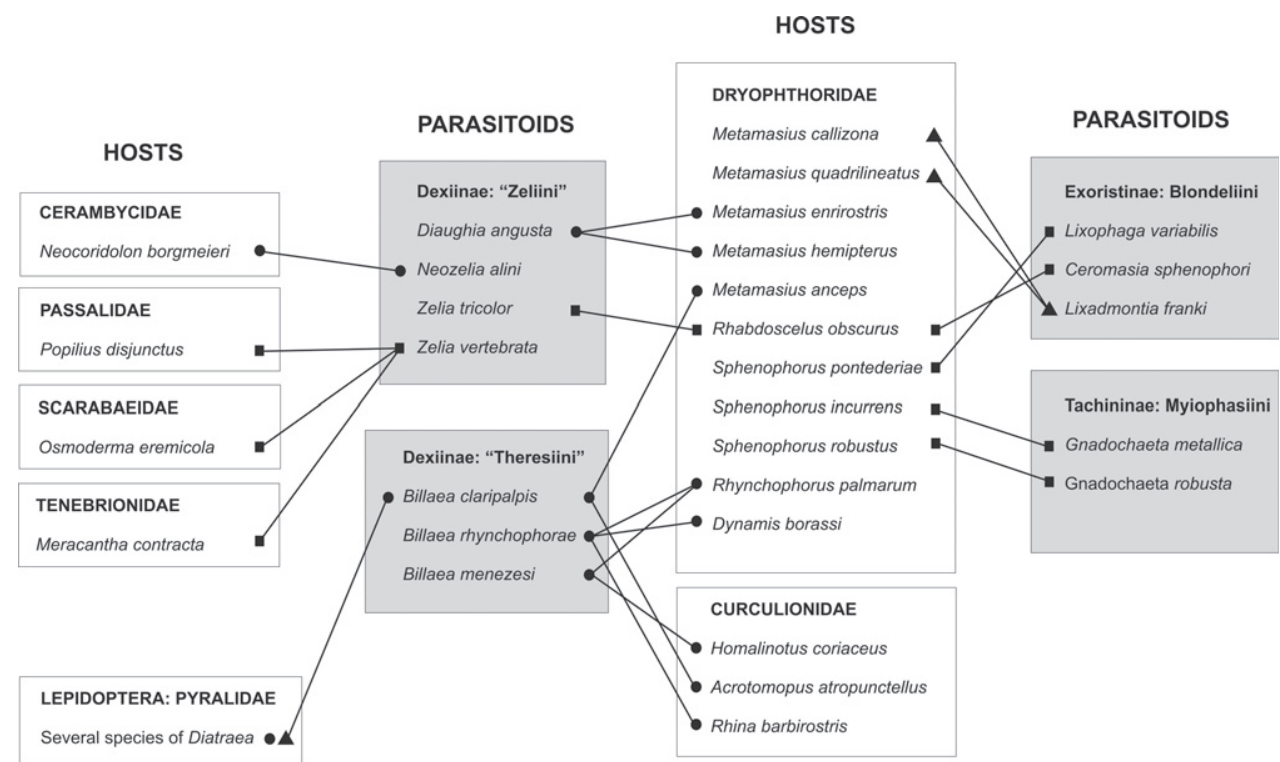

Figure 14. Host-Parasitoid network for Tachinidae, Dryophthoridae and other taxa. Legends: grey boxes = parasitoid taxa; white boxes = host taxa; circles = records in South America; squares = records in North America; triangles = records in Central America. (Sources: Alvarez-Del-Hierro and Cave 1999, Arnaud 1978, Cave 1997, Couturier et al. 1998, Guimarães 1975, 1977, Moura et al. 1993, 2006, Suazo et al. 2006, Wood and Cave 2006).

dae and Curculionidae (Coleoptera) (Guimarães 1977). On its turn, Lixophaga is one of the most diverse genus of Blondeliini in the Americas, with 16 Nearctic and 34 Neotropical species, and the host diversity is also high: Dryophthoridae, Curculionidae, Cerambycidae and Bostrichidae (Coleoptera), and Pyralidae, Arctiidae, Hesperiidae, Noctuidae, Olethreutidae, Gelechiidae, Limacodidae and Tortricidae (Lepidoptera).

However, unlike other Blondeliini, Lixadmontia franki Wood and Cave, 2006 (Tachinidae: Exoristinae: Blondeliini) has some specificity in attacking only species of Metamasius. This tachinid has been considered a potential biological control agent of two species of meristem-boring weevils of bromeliads: M. callizona (Cave 1997, Wood and Cave 2006) and M. quadrilineatus Champion (Alvarez-Del-Hierro and Cave 1999). The later species was reported as being parasitized by $L$. franki only during the larval instars IV, V and VI (Alvarez-Del-Hierro and Cave 1999). As far, the available biological information indicates that there is some specificity in the association between L. franki and M. callizona and M. quadrilineatus.

\section{Conclusion}

Great efforts have been done recently in order to find parasitoids of bromeliad and palm weevils, by searching for parasitoids for the biological control of $M$. callizona in 
Florida (Cave et al. 2003), or by testing the efficiency of parasitoids for the control of R. palmarum in tropical America (Moura et al. 2006).

Although still premature, the use of the tachinid D. angusta as an alternative for the biological control of Metamasius species may be promising, either in its native geographical range or in Central America and tropical North America. On this respect, further studies are needed to test the efficiency of this species under laboratory and natural conditions (through mass hearing and field release). We encourage the community to focus their research on "Zeliini" and "Theresiini" flies while aiming to search for parasitoids of Dryophthoridae and Curculionidae bromeliad and palm pests. Unfortunately, the host records and present knowledge for these tachinids are scattered in the literature. The neotropical "Zeliini" comprises about eleven genera and 18 species, but only four species have some knowledge about their host associations. As for the neotropical "Theresiini", there are about 14 genera and 23 species, but host records are available to only three species. At present, both "Zeliini" and "Theresiini" are included into the large tribe Dexiini.

\section{Acknowledgements}

Thanks to Fábio Gaiger and Sérgio Vanin (IB-USP) for the identification of Metamasius specimens, to Marcia Couri (MNRJ) and Carlos Lamas (MZSP) for the loan of material. James O'Hara and Pierfilippo Cerretti provided suggestions and comments which improved the manuscript. Finnancial support from FAPESP (proc. n. 2004/13663-9 and 2007/50836-7) and fellowship from CNPq (proc. n. 303897/2008-2).

\section{References}

Alvarez-Del-Hierro DR, Cave RD (1999) Ecología de Metamasius quadrilineatus (Coleoptera: Curculionidae) y Admontia sp. (Diptera: Tachinidae) en tres bosques montanos de Honduras. Ceiba 40: 43-49.

Arnaud PH Jr. (1978) A host-parasite catalog of North American Tachinidae (Diptera). USDA, Miscellaneous Publication 1319, Washington D.C., 860 pp.

CABI (2007) Metamasius hemipterus (distribution map). Distribution Maps of Plant Pests: map 229 (1st revision). CABI, Wallingford (UK).

Cave RD (1997) Admontia sp., a potential biological control agent of Metamasius callizona in Florida. Journal of the Bromeliad Society 47: 244-249.

Cave RD, Frank H, Larson BC, Owen M (2003) Exploration for parasitoids of bromeliad weevils in Mesoamerica. Journal of the Bromeliad Society 53: 243-265.

Couturier B, O'Brien CW, Kahn F (1998) Astrocaryum carnosum and A. chonta (Palmae), new hosts for the weevil Dynamis borassi (Curculionidae: Rhynchophorinae). Principes 42: 227-228.

Frank JH (1999) Bromeliad-eating weevils. Selbyana 20: 40-48. 
Frank JH, Cave RD (2005) Metamasius callizona is destroying Florida's native bromeliads. In: Hoddle M (Ed) Second International Symposium on Biological Control of Arthropods. Vol. 1. Davos, Switzerland, September 2005. USDA Forest Service Publication FHTET, 91-101.

Guimarães JH (1971) Family Tachinidae. In: Papavero N (Ed) A catalog of the Diptera of the Americas South of the United States. Museu de Zoologia, Universidade de São Paulo, São Paulo, 333 pp.

Guimarães JH (1975) Neozelia alini, gen et sp. n. (Diptera: Tachinidae), a parasite of cerambycids (Coleoptera), with a listing of Tachinidae parasite of Cerambycidae. Papéis Avulsos de Zoologia 29: 37-44.

Guimarães JH (1977) Host-parasite and parasite-host catalogue of South American Tachinidae (Diptera). Arquivos de Zoologia 28: 1-131.

Herting B (1984) Catalogue of Palearctic Tachinidae (Diptera). Stuttgarter Beiträge zur Naturkunde, Serie A (Biologie) 369: 1-228.

McAlpine JF (1981) Morphology and terminology - adults. In: McAlpine JF, Peterson BV, Shewell GE, Teskey HJ, Vockeroth JR, Wood DM (Coords) Manual of Nearctic Diptera. Vol. 1. Agriculture Canada Research Branch, Monograph 27, Ottawa, 9-63.

Moura JIL, Mariau D, Delabie JHC (1993) Eficiência de Paratheresia menezesi Townsend (Diptera: Tachinidae) no controle biológico natural de Rhynchophorus palmarum (L.) (Coleoptera: Curculionidae). Oleagineux 48: 219-223.

Moura JIL, Toma R, Sgrillo RB, Delabie JHC (2006) Natural efficiency of parasitism by Billaea rhynchophorae (Blanchard) (Diptera: Tachinidae) for the control of Rhynchophorus palmarum (L.) (Coleoptera: Curculionidae). Neotropical Entomology 35: 273-274.

Oehlschlager AC, Chinchilla CM, Gonzalez LM, Jiron LF, Mexzon R, Morgan B (1993) Development of a pheromone-based trapping system for Rhynchophorus palmarum (Coleoptera: Curculionidae). Journal of Economic Entomology 86: 1381-1392.

O'Hara JE, Wood DM (2004) Catalogue of the Tachinidae (Diptera) of America north of Mexico. Memoirs on Entomology (International) 18: 410 pp.

Perty M (1833) Insecta brasiliensia. In his Delectus animalium articulatorum quae in itinere per Brasiliam annis MDCCCVII-MDCCCXX jussu et auspiciis Maximiliani Josephi I. Bavariae regis augustissimi peracto collegerunt Dr. J.B. de Spix et Dr. C.F. Ph. De Martius. Monachii, 125-224.

Reiss F, Schacht W (1983) Die Typen der von J. B. v. Spix und C. F. Ph. v. Martius gesammelten und von M. Perty beschriebenen Dipterenarten (Insecta) in der Zoologischen Staatssammlung München. Spixiana (Suppl.) 9: 307-312.

Silva AGd'A (Coord) (1968) Quarto catálogo dos insetos que vivem nas plantas do Brasil, seus parasitas e predadores. Ministério da Agricultura, Rio de Janeiro, 622 pp.

Stuckenberg, BR (1999) Antennal evolution in the Brachycera (Diptera), with a reassessment of terminology relating to the flagellum. Studia dipterologica 6: 33-48.

Suazo A, Cave RD, Frank JH (2006) Reproductive biology and development of Lixadmontia franki (Diptera: Tachinidae), a parasitoid of bromeliad-eating weevils. Florida Entomologist 91: 453-459. 
Townsend CHT (1936) Manual of Myiology. Part IV. Charles Townsend \& Filhos, Itaquaquecetuba, $303 \mathrm{pp}$.

Townsend CHT (1939) Manual of Myiology. Part IX. Charles Townsend \& Filhos, Itaquaquecetuba, $408 \mathrm{pp}$.

Tschorsnig HP (1985) Taxonomie forstlich wichtiger Parasiten: Untersuchungen zur Struktur des männlichen Postabdomens der Raupenfliegen (Diptera, Tachinidae). Stuttgarter Beiträge zur Naturkunde (Serie A) 383: 1-137.

Vaurie P (1966) A revision of the neotropical genus Metamasius (Coleoptera, Curculionidae, Rhynchophorinae): Species groups I and II. Bulletin of the American Museum of Natural History 131: 211-338.

Wood DM (1987) Tachinidae. In: McAlpine JF, Peterson BV, Shewell GE, Teskey HJ, Vockeroth JR, Wood DM (Coords) Manual of Nearctic Diptera. Vol. 2. Agriculture Canada Research Branch, Monograph 28, Ottawa, 1193-1269.

Wood DM, Cave RD (2006) Description of a new genus and species of weevil parasitoid from Honduras (Diptera: Tachinidae). Florida Entomologist 89: 239-244.

Zorzenon FJ, Bergmann EC, Bicudo JEA (2000) Primeira ocorrência de Metamasius hemipterus (Linnaeus, 1758) e Metamasius ensirostris (Germar, 1824) (Coleoptera, Curculionidae) em palmiteiros dos gêneros Euterpe e Bactris (Arecaceae) no Brasil. Arquivos do Instituto Biológico (Sáo Paulo) 67: 265-268. 